University of Denver

Digital Commons @ DU

Fuel Efficiency Automobile Test Publications Fuel Efficiency Automobile Test Data Repository

$1-21-2015$

\title{
On-Road Heavy-Duty Vehicle Emissions Monitoring System
}

\author{
Gary A. Bishop \\ University of Denver, gbishop@du.edu \\ Rachel Hottor-Raguindin \\ University of Denver \\ Donald H. Stedman \\ University of Denver \\ Peter McClintock \\ Applied Analysis \\ Ed Theobald \\ Envirotest Canada
}

See next page for additional authors

Follow this and additional works at: https://digitalcommons.du.edu/feat_publications

Part of the Environmental Chemistry Commons

\section{Recommended Citation}

Bishop, G.S., Hottor-Raguindin, R., Stedman, D.H., McClintock, P., Theobald, E., Johnson, J.D., Lee, D-W., Zietsman , J., \& Misra, C. (2015). On-road heavy-duty vehicle emissions monitoring system. Environmental Science \& Technology, 49(3),1639-1645. Doi: 10.1021/es505534e

\section{(c) (i) $\ominus$}

This work is licensed under a Creative Commons Attribution-No Derivative Works 4.0 International License. This Article is brought to you for free and open access by the Fuel Efficiency Automobile Test Data Repository at Digital Commons @ DU. It has been accepted for inclusion in Fuel Efficiency Automobile Test Publications by an authorized administrator of Digital Commons @ DU. For more information, please contact jennifer.cox@du.edu,digcommons@du.edu. 


\section{Authors}

Gary A. Bishop, Rachel Hottor-Raguindin, Donald H. Stedman, Peter McClintock, Ed Theobald, Jeremy D. Johnson, Doh-Won Lee, Josias Zietsman, and Chandan Misra 


\section{On-road Heavy-duty Vehicle Emissions Monitoring}

\section{System}

Gary A. Bishop*, Rachel Hottor-Raguindin and Donald H. Stedman

Department of Chemistry and Biochemistry, University of Denver, Denver CO 80208

Peter McClintock

Applied Analysis, 13700 Marina Pointe Dr. Unit 301, Marina Del Rey, CA 90292

Ed Theobald

Envirotest Canada, 207-6741 Cariboo Rd., Burnaby British Columbia, Canada V3N4A3

Jeremy D. Johnson, Doh-Won Lee ${ }^{\dagger}$ and Josias Zietsman

Texas A\&M Transportation Institute, 3135 TAMU, Texas A\&M University, College Station, TX 77843

Chandan Misra

California Air Resources Board, 1001 I St. Sacramento, CA 95814

Abstract

The introduction of particulate and oxides of nitrogen $\left(\mathrm{NO}_{\mathrm{x}}\right)$ after-treatment controls on heavyduty vehicles has spurred the need for fleet emissions data to monitor their reliability and effectiveness. The University of Denver has developed a new method for rapidly measuring 
heavy-duty vehicles for gaseous and particulate fuel specific emissions. The method was recently used to collect 3,088 measurements at a Port of Los Angeles location and a weigh station on I-5 in northern California. The weigh station $\mathrm{NO}_{\mathrm{x}}$ emissions for 2014 models are $73 \%$ lower than 2010 models (3.8 vs. $13.9 \mathrm{gNO}_{\mathrm{x}} / \mathrm{kg}$ of fuel) and look to continue to decrease with newer models. The Port site has a heavy-duty fleet that has been entirely equipped with diesel particulate filters since 2010. Total particulate mass and black carbon measurements showed that only $3 \%$ of the Port vehicles measured exceed expected emission limits with mean $\mathrm{gPM} / \mathrm{kg}$ of fuel emissions of $0.031 \pm 0.007$ and mean $\mathrm{gBC} / \mathrm{kg}$ of fuel emissions of $0.020 \pm 0.003$. Mean particulate emissions were higher for the older weigh station fleet but 2011 and newer trucks gPM/kg of fuel emissions were nevertheless more than a factor of 30 lower than the means for pre-DPF (2007 \& older) model years.

\section{Introduction}

Diesel engines in the United States (US) are major sources of fine particulate matter (PM) and oxides of nitrogen $\left(\mathrm{NO}_{\mathrm{x}}\right)$ even though they generally represent $<5 \%$ of the on-road vehicle fleet. ${ }^{1-4}$ Many of the constituents found in diesel exhaust have also drawn the concerns of health officials for the past several decades ${ }^{5-7}$ For these reasons, reducing diesel exhaust emissions has been a major emphasis of state and federal regulators with the most recent US and California limits for heavy-duty vehicles requiring a PM limit of $0.01 \mathrm{~g} / \mathrm{bhp}-\mathrm{hr}$ (beginning with 2007 engines) and a $\mathrm{NO}_{\mathrm{x}}$ limit of $0.2 \mathrm{~g} / \mathrm{bhp}-\mathrm{hr}$ (beginning with some 2010 engines, Family Emission Limit rules allowing for emissions averaging and the banking and trading of emission credits permitted many 2010 and newer engines to exceed a rigid $0.2 \mathrm{~g} / \mathrm{bhp}$-hr limit until the credits were exhausted). ${ }^{8-13}$ This has led to the introduction of new diesel engine after-treatment systems, most notably the diesel particulate filter (DPF) for PM reduction and selective catalytic 
reduction systems ( $\mathrm{SCR}$ ) for $\mathrm{NO}_{\mathrm{x}}$ control. The long term in-service performance and durability of these devices is unknown and an important research question.

US and California diesel engine emission certification is accomplished with the use of an engine dynamometer and the transient Federal Test Procedure cycle. Recent revisions have included the possibility of on-road compliance monitoring using portable emission monitors (PEMS). ${ }^{14,15}$ These techniques, along with chassis dynamometer testing and on-road testing laboratories, provide highly detailed emission measurements but are limited by cost, time and effort in the number of heavy-duty vehicles (HDV) available for testing making it difficult to follow fleet-wide emission trends, especially when the means are dominated by a small percentage of malfunctioning vehicles. ${ }^{16-18}$

In-use fleet HDV emissions have been studied to date using road-way tunnels, mobile platforms, optical remote sensing and sampling individual truck plumes with a snorkel from bridges and tunnels. Road-way tunnels allow for the unobtrusive measurement of fleet average emissions from large numbers of vehicles at highway speeds but can be limited by location, driving mode and the inability to identify individual vehicles. ${ }^{19-21}$ The use of mobile measurement platforms is a novel approach for capturing vehicle plumes in all types of driving conditions but collecting a plume from a single vehicle and identifying its source can be a challenge. ${ }^{22}$ Optical remote sensing has been used in many locations to collect large numbers of gaseous emission measurements on individual HDV's identified by make and model year but is limited in its ability to collect detailed particle measurements. ${ }^{23-25}$ Sniffing HDV exhaust stacks with a snorkel from an overpass or a tunnel roof is one of the newer approaches that can capture both gaseous and detailed particle data on individual HDV but to date has not linked any make and model year information with the measurements. ${ }^{26-28}$ All of these approaches can provide 
large and robust data sets that when combined can complement one another in the study of fleet emission trends.

Focusing on improving the measurements of individual HDV gaseous and in particular particle emissions, the University of Denver has developed a new technique which we have called the On-road Heavy-duty vehicle emissions Monitoring System (OHMS). To date we have tested the concept in four measurement campaigns. Two previous campaigns were performed in the summer of 2012 at the New Waverly weigh station on I-45 north of Houston TX and the Nordel weigh station in Vancouver, BC. ${ }^{29,30}$ The two most recent campaigns data will be discussed in this paper and were collected in 2013 at a Port of Los Angeles location, previously used for our optical remote sensing measurements, and the Cottonwood weigh station on I-5 near Redding CA. $^{24,25}$

Experimental

OHMS is composed of three basic components, an exhaust collection system, vehicle monitoring equipment and a suite of gas and particle analysis instruments. The exhaust collection system uses an extra-large event tent which can allow a heavy-duty truck to pass safely underneath. The tent acts as a containment system to prevent the exhaust from simply rising and forces it to disperse in all directions, allowing the exhaust collection pipe to capture a sample. The height of the tent has been increased for each measurement campaign as over-height trucks have proven to be more common than expected. The third version used in California, and the first to go unscathed by an over-height truck, is $15.2 \mathrm{~m}$ long, $4.6 \mathrm{~m}$ high and $5.5 \mathrm{~m}$ wide (see Figure 1). On the passenger side of the vehicle is a $3 / 4$ height tent wall, again to help contain the exhaust plume, while the driver side of the tent is open allowing an unobstructed view for the 


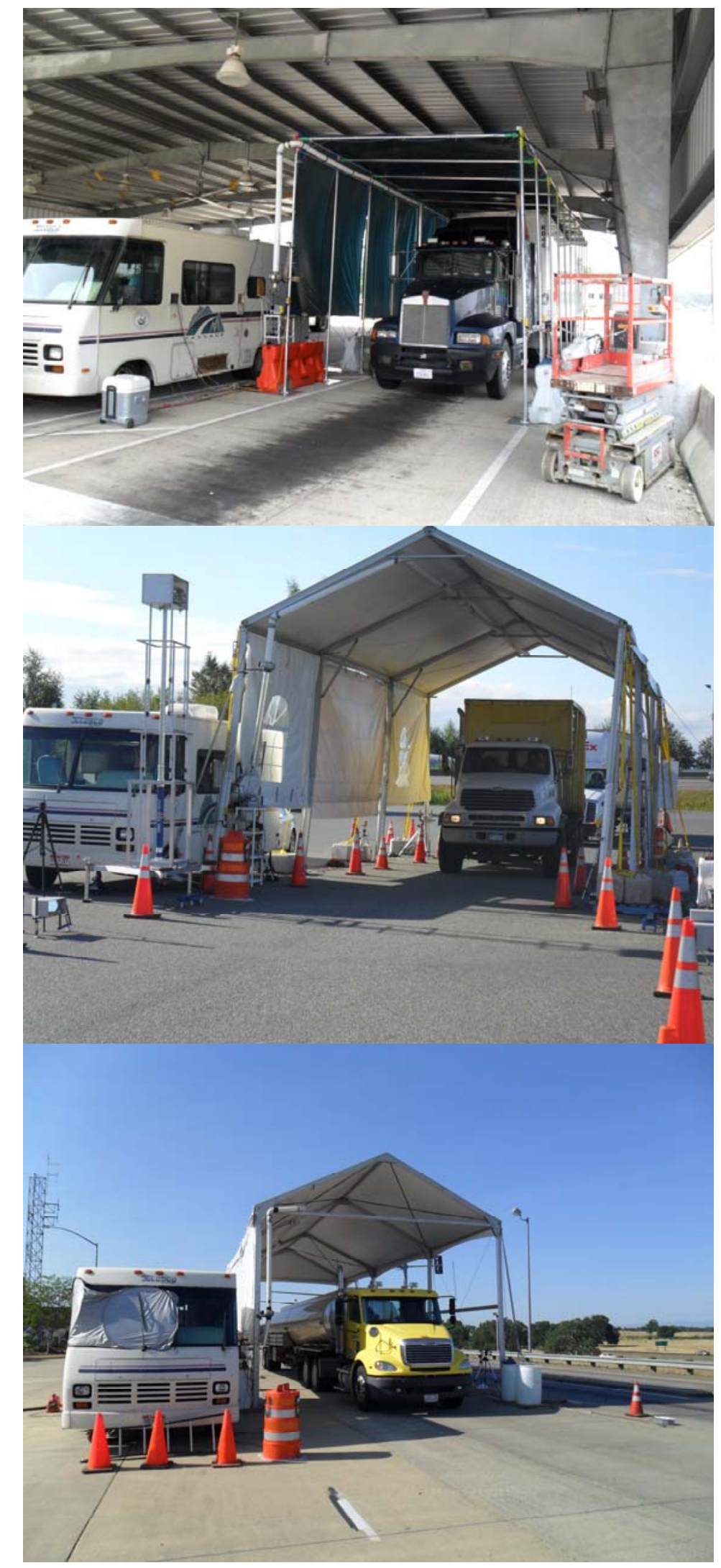

Figure 1. Photographs of OHMS setup in Texas (top), Vancouver BC (middle) and Cottonwood CA (bottom). 
driver. Each tent support standard is held to the ground with concrete weights or two 200 liter water barrels.

Mounted to the tent roof underside on the passenger side of the trucks, is the air intake pipe which is a $15.2 \mathrm{~m}$ long, $10.2 \mathrm{~cm}$ diameter thin wall plastic pipe with holes drilled every $30.5 \mathrm{~cm}$ for a total of 50 holes. The holes gradually decrease in size from $\sim 2.5 \mathrm{~cm}$ at the entrance of the tent to $\sim 6.4 \mathrm{~mm}$ at the exit and are preferably angled toward the roadway. As the truck drives through the tent its exhaust is integrated over the entire $15.2 \mathrm{~m}$. Where the vehicles speed and acceleration matches the air speed in the pipe, fresh exhaust from the truck arrives at each successive hole at the same time the exhaust sampled at the prior holes arrive, thus achieving a spatial and temporal integration of the emissions of the tractor as it drives through the tent. An inline fan (Fantech FG 4XL, $135 \mathrm{cfm}$ ) brings the sampled exhaust down for the sampling lines (see Figure $\mathrm{S} 1$ ). The entire pipe has a residence time of approximately 8 seconds and rapidly dilutes the exhaust in the process by about a factor of 1000 .

Each truck either stops or slows to a crawl before entering the tent where they are encouraged to accelerate as they drive through. The tent is long enough for many vehicles to use multiple gears. Vehicle speeds and accelerations are measured at the entrance and exit of the tent using two pairs of parallel infrared beams (Banner Industries) $1.8 \mathrm{~m}$ apart and approximately $1.2 \mathrm{~m}$ above the roadway. External exhaust pipe temperatures are estimated from thermal images collected on each vehicle using a FLIR Thermovision A20 infrared (IR) camera. The thermographs are manually read and assigned a maximum temperature between 90 to $350^{\circ} \mathrm{C}$ by comparison to a lab created standard using a stainless steel exhaust pipe. The assigned temperatures assume a similar IR emissivity for all in-service exhaust pipes. ${ }^{25}$ Digital images are captured of each vehicle's license plate and of the driver's side of each tractor. The license plates 
are matched against state records for non-personal vehicle information which generally includes make, chassis model year, vehicle identification number (VIN), model and fuel type. The VIN (which we have not decoded) will contain additional engine information but does not include engine certification standards or after-treatment systems installed. For the two California locations license plate information was obtained from the province of British Columbia, CA, and the states of California, Oklahoma, Oregon and Washington. The driver side images are used to identify trucks with diesel exhaust fluid (DEF, 32.5\% urea solution) tanks (not all tanks are on the driver's side and many are hidden) denoting that the tractor is equipped with a $\mathrm{NO}_{\mathrm{x}} \mathrm{SCR}$ system.

The gaseous emission analyzers consist of a Horiba AIA-240 CO and $\mathrm{CO}_{2}$ non-dispersive IR analyzer and two Horiba FCA-240 total hydrocarbon (THC)/nitrogen oxide (NO) or total $\mathrm{NO}_{\mathrm{x}}$ analyzers. THC is only measured in one analyzer using a flame ionization detector while the $\mathrm{NO} / \mathrm{NO}_{\mathrm{x}}$ detection method utilizes ozone chemiluminescence. One FCA-240 is set up to measure only $\mathrm{NO}$ while the second incorporates a catalyst enabling a total $\mathrm{NO}_{\mathrm{x}}(\mathrm{NO}+$ nitrogen dioxide $\left(\mathrm{NO}_{2}\right)$ ) measurement with the difference between the two analyzers equal to the amount of $\mathrm{NO}_{2}$ in the exhaust. The particle measurements use a Dekati Digital Mass Monitor (DMM 230-A), which combines an aerodynamic and mobility particle size distribution measurement, to report total PM mass and particle number and a Droplet Measurement Technologies Photoacoustic Extinctiometer (PAX, measures at 870nm) for detection of BC or soot (see Table S1 for analyzer specifications). ${ }^{31}$ The Dekati DMM 230-A has been previously shown to correlate well with filter-based methods at the 2007 Federal PM standard. ${ }^{32}$ All species are measured as a ratio to $\mathrm{CO}_{2}$ (see Figures $\mathrm{S} 2$ - S5). 
The $\mathrm{CO}_{2}$ analyzer's maximum span adjustment is set at each site using a certified mixture of $3.5 \% \mathrm{CO}_{2}$ in nitrogen (Air Liquide). All of the analyzers are adjusted to have a positive offset when sampling background air to preclude negative concentrations. Time alignment of the analyzers data streams at each site are accomplished by filling a plastic syringe with all of the gaseous species and a small amount of black smoke and injecting it about $0.5 \mathrm{~m}$ above the inline fan while recording all of the channels at $1 \mathrm{~Hz}$. Peak positions relative to the $\mathrm{CO}_{2}$ peak are then stored by the data collection computer and used for time alignment during the analysis. Daily calibrations of the analyzers are made with multiple injections of a Bar-97 certified low-range calibration gas $\left(0.5 \% \mathrm{CO}, 6 \% \mathrm{CO}_{2}, 200 \mathrm{ppm}\right.$ propane, 300ppm $\mathrm{NO}$ in nitrogen) above the inline fan and averaging the measured $\mathrm{CO} / \mathrm{CO}_{2}, \mathrm{HC} / \mathrm{CO}_{2}, \mathrm{NO} / \mathrm{CO}_{2}$ and $\mathrm{NO}_{\mathrm{x}} / \mathrm{CO}_{2}$ ratios and then dividing by the certified ratios. The results are then used to scale all of the measured vehicle emission ratios (see Table S2). The Dekati PM analyzer was calibrated by the factory and does not require any additional field calibrations. The PAX BC instrument was calibrated in the laboratory according to its standard operating procedures using aerosolized ammonium sulfate particles for scatter and soot particles from a propane flame for absorption.

The gas analyzers are fed by a twin piston diaphragm pump (KNF Neuberger, Inc. UN035.1.2ANP) delivering 55 1/min of exhaust via $1 / 4$ ” Teflon tubing via a water condensation trap. The two particle instruments each have internal sampling pumps and are fed by a separate 1/4" copper line (Figure S1 provides a schematic of the layout). An IR body sensor positioned near the exit of the tent triggers the collection of 15 or $20 \mathrm{~s}$ (depending on the site) of emissions data at $1 \mathrm{~Hz}$ from all of the analyzers as the truck is exiting the tent. The emissions time series for each instrument are time aligned and if sufficient amounts of $\mathrm{CO}_{2}$ are detected (minimum requirements were for a 75ppm rise above background) then each species is correlated to $\mathrm{CO}_{2}$ 
and a linear least squares line is fit to determine each slope (see Figures S2-S5). The slopes are divided by the instrument ratio adjustment factor, previously determined with the certified calibration gases, and converted into fuel-specific emissions of grams of pollutant per kilogram of fuel burned $(\mathrm{g} / \mathrm{kg})$ by carbon balance using the molecular weight of each species and 0.86 as diesel fuel's carbon mass fraction.

We conducted five days of emission measurements using the OHMS system at the Port of Los Angeles on lane \#1 at the Water St. exit gate from the TRAPAC Inc. container operations (berths 135-139, April 22 - 26, 2013) in the South Coast Air Basin, that has been the site of 4 previous measurement campaigns with our optical remote exhaust sensing system (FEAT), and at the California Highway Patrol Cottonwood weigh station in northern CA (May 6 - 10, 2013) on northbound I-5 (bottom photo Figure 1). ${ }^{24,25}$ The final emission databases with vehicle registration information for each site will be available for download from our website at $\underline{\text { www.feat.biochem.du.edu. }}$

\section{Results and Discussion}

The OHMS measurement technique has evolved and been improved with each setup. The dimensions of the tent have changed slightly with each successive campaign, especially the height which was increased each time due to collisions with over height trucks (see Figure 1). The proof of concept tests in Texas experienced the most problems with high temperature and humidity levels necessitating improvements in the water trap design and proving intolerable for two PAX BC detectors (which has since been corrected by the manufacturer). In addition both of our previous studies suffered a likely over-estimation of $\mathrm{NO}_{2}$ and total $\mathrm{NO}_{\mathrm{x}}$ emissions due to 
poor field calibrations used to estimate the $\mathrm{NO}_{\mathrm{x}}$ analyzers $\mathrm{NO}_{2}$ conversion efficiencies which has also been corrected (see Supporting Information).

Table 1 summarizes the data collected for the two California locations with sampling dates, number of trucks successfully measured, their mean model year, fuel specific mean emissions with standard errors of the mean calculated from the daily means, mean speeds and accelerations at the entrance and exit of the tent and the estimated mean IR exhaust temperatures of the trucks' external exhaust pipes. $\mathrm{NO}_{2}$ emissions are calculated by taking the difference between the total $\mathrm{NO}_{\mathrm{x}}$ analyzer and the $\mathrm{NO}$ analyzer. The accelerated retirement program previously instituted by the Ports of Long Beach and Los Angeles mandated that all vehicles serving the port meet the Federal 2007 PM emissions standard by $2010 .{ }^{33}$ Consequently, HDV's at the Port are newer. The interstate truck fleet observed at the Cottonwood weigh station is approximately 3.5 years older than the Port fleet and has higher mean $\mathrm{CO}$ and particulate emissions as a result, while the oxides of nitrogen mean emissions are similar. The higher than expected oxides of nitrogen emissions for the newer Port fleet have been reported before and are likely due to several factors including the slower speeds and higher load driving mode of accelerating their loads from a complete stop. ${ }^{24,25}$ Port operations can lead to low exhaust temperatures, poor SCR operation and higher $\mathrm{NO}_{\mathrm{x}}$ emissions on the 2010 compliant HDV's. ${ }^{34}$ In addition, although the Port fleet is newer, there are fewer 2010 compliant HDV (only $11 \%$ of the Port fleet compared to $18 \%$ of the weigh station fleet).

We last measured HDV emissions at the Port of Los Angeles with FEAT in the spring of 2012 when the fleet mean chassis model year averaged 2009.3 which has changed little in the intervening year (2009.1 average for the 2013 measurements). The OHMS measurements have lower gCO $/ \mathrm{kg}$ of fuel $(2.3 \pm 0.4 \mathrm{OHMS}$ vs $8.2 \pm 0.6 \mathrm{FEAT})$ and $\mathrm{gHC} / \mathrm{kg}$ of fuel $(0.20 \pm 0.03 \mathrm{OHMS}$ 
Table 1. 2013 Summary of California Measurement Dates, Fleet Information, Mean Fuel Specific Emissions, Speeds and Accelerations, IR Exhaust Temperatures and Standard Errors of the Mean.

\begin{tabular}{|c|c|c|c|c|c|c|c|c|}
\hline $\begin{array}{l}\text { Location } \\
\text { Date } \\
\text { Roadway Slope }\end{array}$ & $\begin{array}{l}\text { HDV } \\
\text { Mean } \\
\text { MY }\end{array}$ & $\mathrm{gCO} / \mathrm{kg}$ & $\mathrm{gHC} / \mathrm{kg}$ & $\mathrm{gNO}^{\mathrm{a}} / \mathrm{kg} / \mathrm{gNO}_{2} / \mathrm{kg} / \mathrm{gNO}_{\mathrm{x}}^{\mathrm{b}} / \mathrm{kg}$ & $\mathrm{gPM} / \mathrm{kg}$ & $\mathrm{gBC} / \mathrm{kg}$ & $\begin{array}{l}\text { Entrance / Exit } \\
\text { Speed }^{\mathrm{c}} \\
\text { Acceleration }^{\mathrm{d}}\end{array}$ & $\begin{array}{l}\text { IR Exhaust } \\
\text { Temperature } \\
{ }^{\circ} \mathrm{C}\end{array}$ \\
\hline $\begin{array}{l}\text { Port of LA } 2013 \\
\text { April 22-26 } \\
0^{\circ}\end{array}$ & $\begin{array}{l}1222 \\
2009.1\end{array}$ & $2.3 \pm 0.4$ & $0.20 \pm 0.03$ & $12.4 \pm 0.3 / 2.3 \pm 0.3 / 20.7 \pm 0.8$ & $0.031 \pm 0.007$ & $0.02 \pm 0.003$ & $\begin{array}{l}7.7 / 9.3 \\
0.4 / 0.5\end{array}$ & $172^{\circ} \pm 2$ \\
\hline $\begin{array}{l}\text { Cottonwood } 2013 \\
\text { May 6-10 } \\
-0.5^{\circ}\end{array}$ & $\begin{array}{l}1866 \\
2005.6\end{array}$ & $5.1 \pm 0.2$ & $0.25 \pm 0.04$ & $10.6 \pm 0.4 / 3.5 \pm 0.1 / 20.3 \pm 0.7$ & $0.65 \pm 0.11$ & $0.23 \pm 0.03$ & $\begin{array}{l}15.7 / 16.8 \\
1.1 / 0.9\end{array}$ & $210^{\circ} \pm 10$ \\
\hline
\end{tabular}

grams of NO

${ }^{b}$ grams of $\mathrm{NO}_{2}$

${ }^{\mathrm{c}}$ kilometers per hour

${ }^{d}$ kilometers per hour / sec 


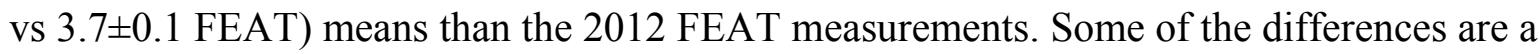
direct result of the fleet differences between the two studies. In 2013 the OHMS system measured fewer natural gas powered trucks (3\% OHMS vs 16\% FEAT) than measured in 2012 by FEAT which have significantly higher $\mathrm{CO}$ and methane emissions. Figure 2 compares the mean $\mathrm{gNO}_{\mathrm{x}} / \mathrm{kg}$ of fuel emissions by model year measured in 2013 with OHMS at the Port of Los Angeles and the Cottonwood weigh station to our 2012 FEAT measurements at the same Port location and the Peralta weigh station in the South Coast Air Basin in the Anaheim Hills. ${ }^{25}$ The error bars plotted are standard errors of the mean determined from the daily means. In general, chassis model years are a year older than the vehicles engine and it is the engines year of manufacture which defines Federal certification standards. At the Port the agreement between the two methods is quite good with the fleet mean emissions being statistically identical for the OHMS and FEAT data sets showing no emission deterioration during the intervening year.

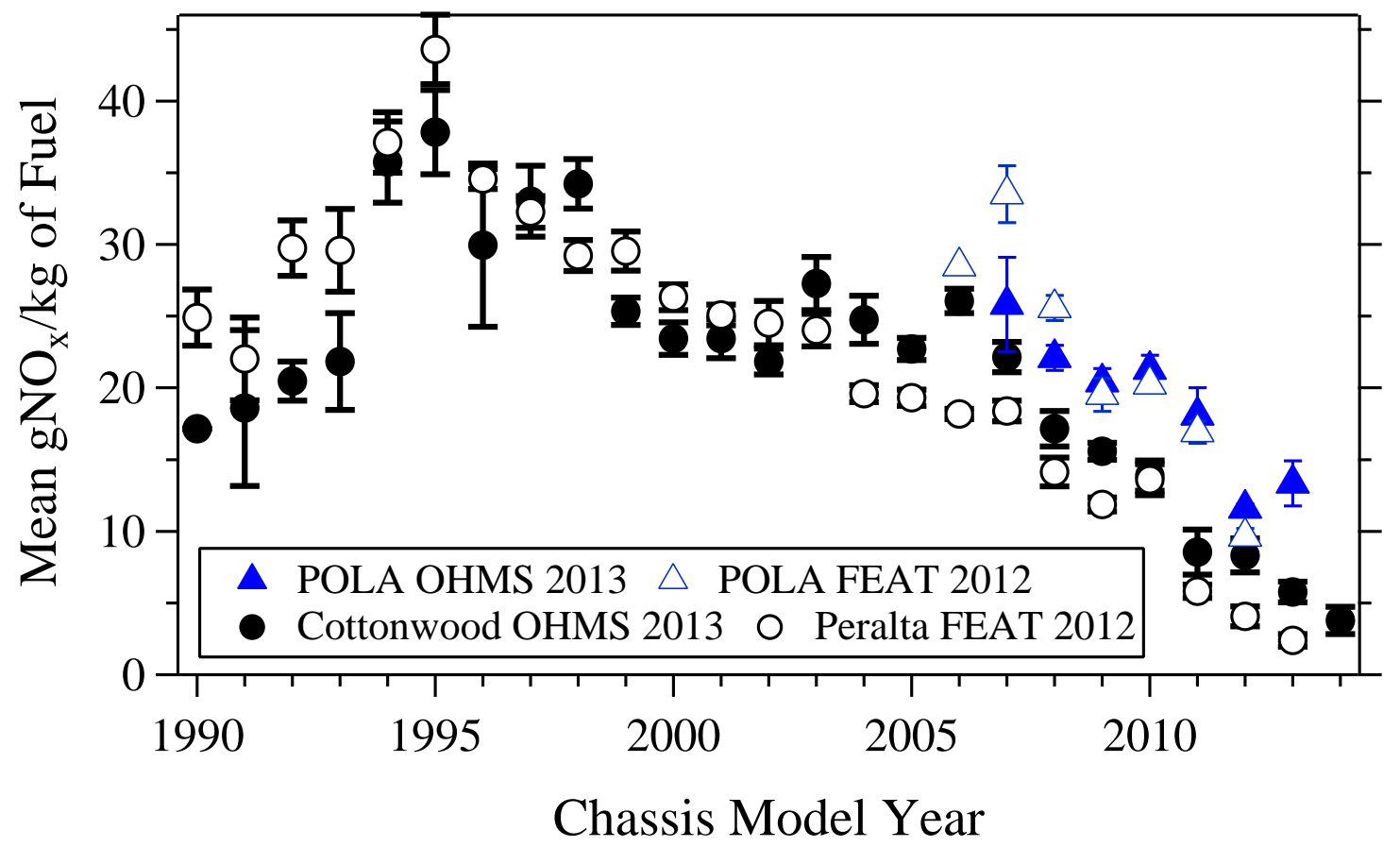

Figure 2. Mean $\mathrm{gNOx} / \mathrm{kg}$ of fuel emissions versus chassis model year comparison between the OHMS results (filled symbols) and the 2012 FEAT optical measurements (open symbols) at the Port of Los Angeles site and the Cottonwood and Peralta weigh station locations. Error bars are standard errors of the means calculated from the daily means. 
There are physical differences between the two weigh station sites with Peralta having an uphill exit compared to Cottonwoods slightly downhill grade and the entrance ramp at Cottonwood is significantly longer ( $1.1 \mathrm{~km}$ vs $0.3 \mathrm{~km}$ ), which may account for the Cottonwood truck's having slightly lower average IR exhaust temperatures $\left(210^{\circ} \mathrm{C}\right.$ vs $\left.225^{\circ} \mathrm{C}\right)$. Speeds and accelerations are also slightly higher at Peralta. With these caveats the emission trends in Figure 2 are similar at the two weigh stations with the highest $\mathrm{NO}_{\mathrm{x}}$ emissions during the late 90 's followed by a gradual reduction until the 2011 models when a much faster reduction rate is observed as newer SCR equipped trucks are introduced. Because the Federal 2010 HDV engine regulations allowed manufacturers the use of emission credits to phase in 2010 compliant engines we still have not measured a fleet model year where all of the truck engines meet the 0.2 g/bhp-hr $\mathrm{NO}_{\mathrm{x}}$ standard. The 2014 model year trucks at Cottonwood (28 total) have mean $\mathrm{NO}_{\mathrm{x}}$ emissions of $3.8 \mathrm{~g} / \mathrm{kg}$ of fuel which is about 3 times higher than an interpolated on-road standard of $1.33 \mathrm{~g} / \mathrm{kg}$ of fuel by converting the $0.2 \mathrm{~g} / \mathrm{bhp}-\mathrm{hr}$ standard into $\mathrm{g} / \mathrm{kg}$ of fuel emissions assuming $0.15 \mathrm{~kg}$ of fuel are consumed per bhp-hr. ${ }^{35}$

The key advantage of the OHMS measurement system over FEAT is its ability to make particulate measurements. To date there have only been a few studies in the literature that have reported particulate results for DPF equipped vehicles and a comparison of those results with the OHMS measurements is provided in Table 2. Taking into account the load differences (a 4\% grade at highway speeds in the Caldecott Tunnel) and three years of fleet turnover to lower emitting HDV our $0.23 \pm 0.03 \mathrm{gBC} / \mathrm{kg}$ of fuel for the Cottonwood fleet is in general agreement with on-road aethalometer measurements reported by Dallmann et al. and statistically identical to the value reported by Kozawa et al. ${ }^{22,26,27}$ For 2011 and newer trucks our Port PM and BC measurements (133 measurements) are statistically similar to the values May et al. reported for a 
Table 2. OHMS Particulate Emission Measurement Comparisons with Reported Literature Values.

\begin{tabular}{|c|c|c|c|c|c|}
\hline $\begin{array}{l}\text { Location } \\
\text { (Tests / Samples) }\end{array}$ & Source & $\begin{array}{l}\text { Chassis } \\
\text { Model Year }\end{array}$ & Mean gPM/kg & Mean $\mathrm{gBC} / \mathrm{kg}$ & Mean gEC/kg \\
\hline $\begin{array}{l}\text { Laboratory } \\
\text { (19) }\end{array}$ & $\begin{array}{l}\text { Khalek } \\
\text { et al. }\end{array}$ & 2011 & 0.0006 & & 0.0001 \\
\hline $\begin{array}{l}\text { Caldecott Tunnel } \\
(667)\end{array}$ & $\begin{array}{l}\text { Dallmann } \\
\text { et al. }\end{array}$ & N.A. & & $0.54 \pm 0.07^{\mathrm{a}}$ & \\
\hline $\begin{array}{l}\text { Port of Oakland } \\
\text { (418) }\end{array}$ & $\begin{array}{l}\text { Dallmann } \\
\text { et al. }\end{array}$ & N.A. & & $0.49 \pm 0.08^{\mathrm{a}}$ & \\
\hline $\begin{array}{l}\text { Laboratory } \\
\text { (13) }\end{array}$ & May et al. & 2010 & $0.007 \pm 0.004^{b}$ & & $0.0007 \pm 0.002^{b}$ \\
\hline $\begin{array}{l}\text { Laboratory } \\
\text { (12) }\end{array}$ & May et al. & 2007 & $0.15 \pm 0.14^{\mathrm{b}}$ & & $0.0008 \pm 0.0003^{\mathrm{b}}$ \\
\hline $\begin{array}{l}\text { Laboratory } \\
\text { (18) }\end{array}$ & May et al. & pre-2008 & $0.51 \pm 0.05^{\mathrm{b}}$ & & $0.18 \pm 0.03^{b}$ \\
\hline $\begin{array}{l}\text { Mobile Platform } \\
\text { (N.A.) }\end{array}$ & $\begin{array}{l}\text { Kozawa } \\
\text { et al. }\end{array}$ & N.A. & & $0.18 \pm 0.1^{\mathrm{c}}$ & \\
\hline $\begin{array}{l}\text { Port of LA } \\
\text { (133) }\end{array}$ & This Work & $\begin{array}{l}2011 \\
\& \text { newer }\end{array}$ & $0.009 \pm 0.004^{b}$ & $0.004 \pm 0.006^{\mathrm{b}}$ & \\
\hline $\begin{array}{l}\text { Port of LA } \\
(1070)\end{array}$ & This Work & $2008-2010$ & $0.034 \pm 0.007^{\mathrm{b}}$ & $0.022 \pm 0.003^{b}$ & \\
\hline $\begin{array}{l}\text { Cottonwood } \\
(335)\end{array}$ & This Work & $\begin{array}{l}2011 \\
\& \text { newer }\end{array}$ & $0.03 \pm 0.01^{\mathrm{b}}$ & $0.013 \pm 0.005^{\mathrm{b}}$ & \\
\hline $\begin{array}{l}\text { Cottonwood } \\
(391)\end{array}$ & This Work & $2008-2010$ & $0.3 \pm 0.2^{b}$ & $0.059 \pm 0.009^{\mathrm{b}}$ & \\
\hline $\begin{array}{l}\text { Cottonwood } \\
(1094)\end{array}$ & This Work & pre-2008 & $0.96 \pm 0.12^{b}$ & $0.36 \pm 0.04^{b}$ & \\
\hline
\end{tabular}

${ }^{a} 95 \%$ confidence intervals $/{ }^{b}$ Standard errors of the mean $/{ }^{c}$ One standard deviation 
2010 truck and only slightly higher than the data reported by Khalek et al. on 2010 engines. ${ }^{16,36}$ The PM and $\mathrm{BC}$ emissions for this group are higher at Cottonwood. Both California locations sampled for the 2008 - 2010 model year group have higher BC emissions than the single DPF equipped 2007 truck May et al. measured while the total PM measurements fall on either side. For non-DPF equipped trucks (generally pre-2008 chassis model years and older) the on-road measurements from Cottonwood are higher for both PM and BC than the 3 vehicles May et al. tested in the laboratory. ${ }^{16}$ This is not surprising since we have access to many more vehicles which are unaware that they are going to be tested.

Figures 3 and 4 are box and whisker plots by chassis model year for the total PM (left grey shaded bars) and BC (right white bars) measurements collected at the Port of Los Angeles and the Cottonwood weigh station. The box is defined as the $25^{\text {th }}, 50^{\text {th }}$ and $75^{\text {th }}$ percentiles, the whiskers extend from the $10^{\text {th }}$ to the $90^{\text {th }}$ percentiles and the data points are the measurements beyond these percentiles. The filled square is the mean value and split y-axes are used to cover the range of values while preserving some of the detailed distribution of the majority of lower emitting vehicles. Within similar technology groups we have aggregated some model years. The negative ratios reported provide a built in indicator for the noise level of the technique and a level above which an individual measurement's significance can be judged. Negative ratios occur when a zero emissions ratio (slope $=0$ ) has noise that results in a fit with a negative slope. For a truly zero sample we would expect half the readings to be negative and half positive with a zero average. Negative results have not been removed and are included as measured in all of the calculations.

In general, both PM and $\mathrm{BC}$ mean emissions increase with age and $\mathrm{BC}$ emissions are lower than the total PM measurements. Beginning with the 2008 chassis model year vehicles in Figure 


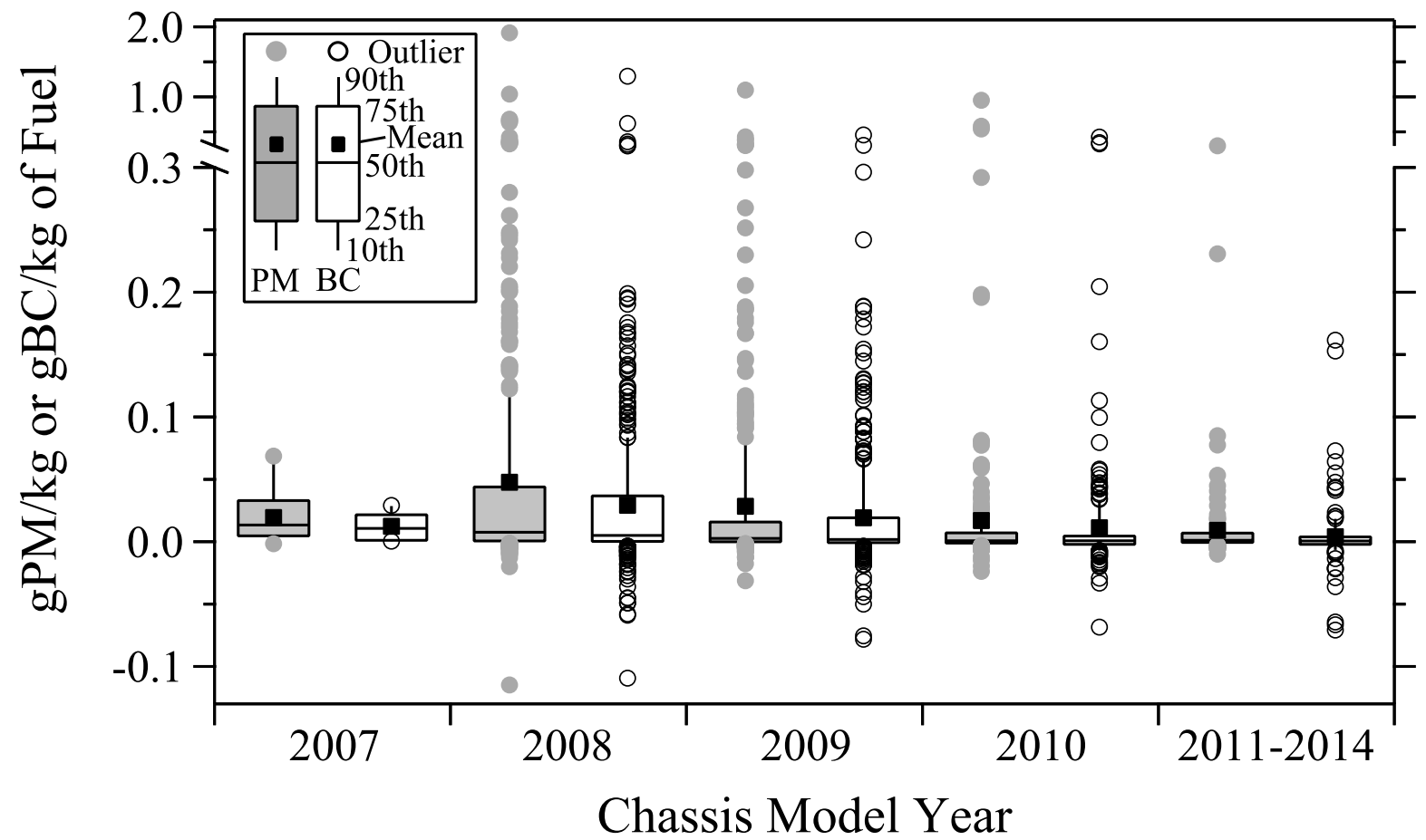

Figure 3. A box and whisker plot of $\mathrm{gPM} / \mathrm{kg}$ (left and shaded) and $\mathrm{gBC} / \mathrm{kg}$ of fuel (right) with a split y-axis versus chassis model year for measurements collected at the Port of Los Angeles. The box is defined as the $25^{\text {th }}, 50^{\text {th }}$ and $75^{\text {th }}$ percentiles, the whiskers extend from the $10^{\text {th }}$ to the $90^{\text {th }}$ percentiles, the circles lie beyond these percentiles and the filled square is the mean.

4 it is clearly evident when the introductions of DPFs occurred. Due to the limited number of model years in operation at the Port the y-axis in Figure 3 can be expanded to see the details of the inter-quartile range for each model year grouping. The size of the inter-quartile range, the extent of the outliers and the skewness of the distribution (mean/median ratio increases) can be seen to increase with each successive model year group for both the PM and BC emissions. One is tempted to speculate that this is the result of DPF deterioration but that determination will have to wait until we have additional data sets in order to distinguish "age" from model year. Again assuming that $0.15 \mathrm{~kg}$ of fuel is consumed per brake-horsepower we can convert the Federal 0.01 $\mathrm{g} / \mathrm{bhp}-\mathrm{hr}$ PM standard to $0.07 \mathrm{gPM} / \mathrm{kg}$ of fuel. If we follow light-duty OBDII “check engine light" logic and only consider trucks with emissions that are 3 times this standard $(0.21 \mathrm{gPM} / \mathrm{kg})$ 


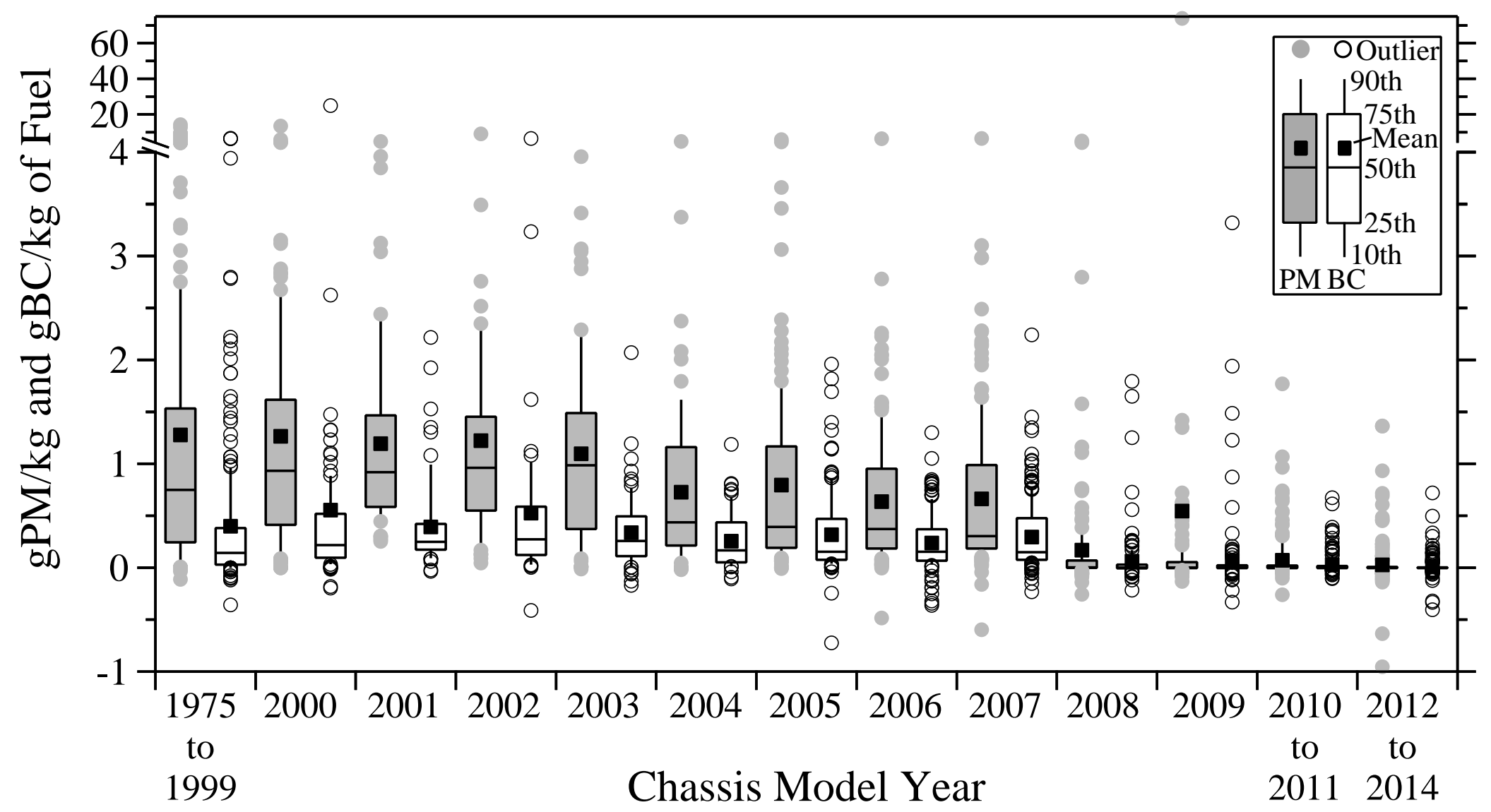

Figure 4. A box and whisker plot of gPM/kg (left and shaded) and $\mathrm{gBC} / \mathrm{kg}$ of fuel (right) with a split y-axis versus chassis model year for measurements collected at the Cottonwood weigh station. The box is defined as the $25^{\text {th }}, 50^{\text {th }}$ and $75^{\text {th }}$ percentiles, the whiskers extend from the $10^{\text {th }}$ to the $90^{\text {th }}$ percentiles, the circles lie beyond these percentiles and the filled square is the mean. 
we find only $3 \%$ of the 2007 and newer vehicles at the Port have PM measurements that exceed this level (40/1213) with 2010 and newer trucks contributing only 6 of these exceedances (6/359).

At the Cottonwood weigh station there are more measurements above $0.21 \mathrm{gPM} / \mathrm{kg}$ of fuel with $9 \%$ of the 2008 and newer trucks (67/726), which also includes a higher percentage of 2010 and newer vehicles (31/432) than at the Port. The largest gPM/kg of fuel measurement was recorded from a 2009 Kenworth, whose white smoke emissions were $73.8 \mathrm{~g} / \mathrm{kg}$ of fuel, accounting for the large increase in the 2009 mean PM emissions. The pre-DPF equipped trucks measured at Cottonwood (generally 2007 and older), as expected have consistently higher PM and BC emissions with a noticeable limit in emissions around $20 \mathrm{~g} / \mathrm{kg}$. There are two exceptions, a 2000 Peterbilt with BC emissions of $25 \mathrm{~g} / \mathrm{kg}$ of fuel and the 2009 Kenworth previously mentioned. Since both particle instruments have cut-offs on the maximum size of particles that can be sampled this will produce an upper limit on the measurements that will be difficult to exceed without a significant increase in the total number of small particles and that may be the case for these two vehicles.

Figure 5 plots the $\mathrm{gBC} / \mathrm{kg}$ of fuel against $\mathrm{gPM} / \mathrm{kg}$ of fuel for the 107 vehicles at both locations, selected for PM emissions greater than $0.21 \mathrm{gPM} / \mathrm{kg}$. If we exclude the 2009 Kenworth from the Cottonwood correlation, the increases in total particle mass correlate well $\left(\mathrm{R}^{2}\right.$ of 0.75 with a slope of 0.4 at Cottonwood and $\mathrm{R}^{2}$ of 0.93 with a slope of 0.6 at the Port) with the increases in BC. The Cottonwood data's (67 measurements from 65 vehicles, filled circles) BC measurements are obviously noisier than similar measurements at the Port of Los Angeles (40 measurements from 36 vehicles, empty triangles). Contributing factors may include having to use generator power at Cottonwood and its audible noise affecting the PAX unit. Also the 


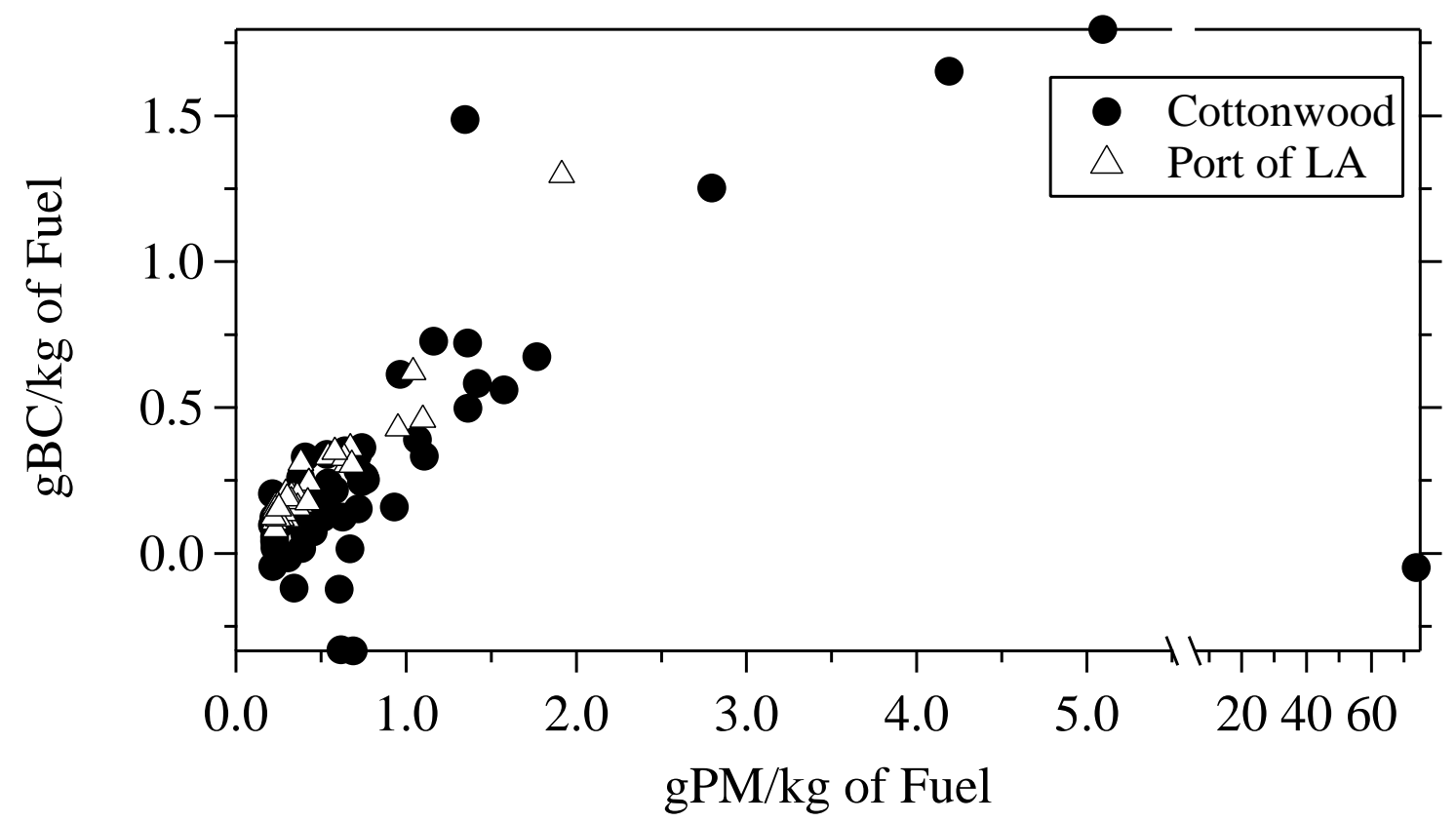

Figure 5. Emissions of $\mathrm{gBC} / \mathrm{kg}$ of fuel versus $\mathrm{gPM} / \mathrm{kg}$ of fuel for $\mathrm{HDV}$ at the Cottonwood weigh station (filled circles) and the Port of Los Angeles (empty triangles) for HDV with a $\mathrm{gPM} / \mathrm{kg}$ of fuel emissions greater than $0.21 \mathrm{gPM} / \mathrm{kg}$ of fuel.

exhaust plumes at Cottonwood on average were smaller (maximum $\mathrm{CO}_{2}$ of $\Delta 350 \mathrm{ppm}$ vs $\Delta 400 \mathrm{ppm}$ at the Port) and all of the larger negative $\mathrm{gBC} / \mathrm{kg}$ of fuel measurements in Figure 5 are associated with small plumes.

Confounding sources of emissions exist from transportation refrigeration units (TRUs) and emissions from the contents of the trailers. We were able to identify 62 vehicles that had active TRUs but saw no significant changes in $\mathrm{NO}_{\mathrm{x}}$ or particulate emissions. Since TRU engines cycle with temperature demand we were not able to certify that the engine was actually in-use. We were also able to identify 90 vehicles with cattle transport trailers in tow. These vehicles increase the mean $\mathrm{gHC} / \mathrm{kg}$ of fuel emission by $\sim 12 \%$ which is undoubtedly an increase in methane emissions from the contents of the trailers. 
Going forward the OHMS measurement method is a new tool that can be used to collect large numbers of gaseous and particulate emission measurements from in-use heavy-duty fleets in the US. The results discussed here are already a significant contribution to realistic on-road HDV emissions data; we currently have plans to repeat the measurements at the two California locations in the spring of 2015 and 2017 which will hopefully allow us to study the important issue of in-use deterioration of these vehicles $\mathrm{NO}_{\mathrm{x}}$ and $\mathrm{PM}$ after-treatment systems. It is also possible to envision using this method at permanent locations that would allow year round sampling to capture even larger segments of the HDV fleet.

\section{ASSOCIATED CONTENT}

Supporting Information. Supplementary figures (S1 to S7) and Tables (S1 to S2) referenced in the text. This material is available free of charge via the Internet at http://pubs.acs.org."

\section{AUTHOR INFORMATION}

\section{Corresponding Author}

*Phone (303) 871-2584. Email: gbishop@du.edu.

Present Addresses

${ }^{\dagger}$ D-W.L.: California Air Resources Board, 9480 Telstar Ave. Suite 4, El Monte, CA 91731. Author Contributions

The manuscript was written through contributions of all authors. All authors have given approval to the final version of the manuscript. 


\section{ACKNOWLEDGMENT}

This paper is a result of work supported by the California Environmental Protection Agency Air Resources Board (11-309), the North Central Texas Council of Governments, Envirotest Canada and the University of Denver. Results and conclusions presented here are solely the responsibility of the authors and may not represent the views of the sponsors. The authors would like to gratefully acknowledge TraPac and the California Highway Patrol for hosting our California measurements and Ian Stedman for support services.

\section{REFERENCES}

1. Dallmann, T. R.; Harley, R. A., Evaluation of mobile source emission trends in the United States. J. Geo. Res. : Atm 2010, 115, D14305-D14312, DOI: 10.1029/2010JD013862.

2. McDonald, B. C.; Dallmann, T. R.; Martin, E. W.; Harley, R. A., Long-term trends in nitrogen oxide emissions from motor vehicles at national, state, and air basin scales. J. Geo. Res.: Atm. 2012, 117, (D18), 1-11, DOI: 10.1029/2012jd018304.

3. McDonald, B. C.; Gentner, D. R.; Goldstein, A. H.; Harley, R. A., Long-Term Trends in Motor Vehicle Emissions in U.S. Urban Areas. Environ. Sci. Technol. 2013, 47, (17), 1002210031, DOI: 10.1021/es401034z.

4. Pollack, I. B.; Ryerson, T. B.; Trainer, M.; Parrish, D. D.; Andrews, A. E.; Atlas, E. L.; Blake, D. R.; Brown, S. S.; Commane, R.; Daube, B. C.; de Gouw, J. A.; Dubé, W. P.; Flynn, J.; Frost, G. J.; Gilman, J. B.; Grossberg, N.; Holloway, J. S.; Kofler, J.; Kort, E. A.; Kuster, W. C.; Lang, P. M.; Lefer, B.; Lueb, R. A.; Neuman, J. A.; Nowak, J. B.; Novelli, P. C.; Peischl, J.; Perring, A. E.; Roberts, J. M.; Santoni, G.; Schwarz, J. P.; Spackman, J. R.; Wagner, N. L.; Warneke, C.; Washenfelder, R. A.; Wofsy, S. C.; Xiang, B., Airborne and ground-based observations of a weekend effect in ozone, precursors, and oxidation products in the California 
South Coast Air Basin. J. Geo. Res. : Atm 2012, 117, (D00V05), 1-14, DOI:

10.1029/2011JD016772.

5. Office of Environmental Health Hazard Assessment; California Environmental Protection Agency, Part B: Health risk assessment for diesel exhaust; Sacramento, 1998; http://www.arb.ca.gov/regact/diesltac/partb.pdf.

6. California Air Resources Board, Risk Reduction Plan to Reduce Particulate Matter Emissions from Diesel-fueled Engines and Vehicles; Sacramento, CA, 2000; http://www.arb.ca.gov/diesel/documents/rrpfinal.pdf.

7. Health Effects Institute, Traffic-related Air Pollution: A Critical Review of the Literature on Emissions, Exposure, and Health Effects. A Special Report of the HEI Panel of the Health Effects of Traffic-related Air Pollution; 2010; http://pubs.healtheffects.org/getfile.php?u=553. 8. Code of Federal Regulations, $\mathrm{NO}_{\mathrm{x}}$ and particulate averaging, trading and banking for heavy-duty engines. Title 40, Section 86.007-15, 2001.

9. Code of Federal Regulations, Emission standards and supplemental requirements for 2007 and later model year diesel heavy-duty engines and vehicles. Title 40 Section 86.007-11, 2008.

10. U. S. Environmental Protection Agency; Air and Radiation, Highway diesel progress review; EPA420-R-02-016; 2002; www.epa.gov/oms/highwaydiesel/compliance/420r02016.pdf.

11. California Code of Regulations, Regulation to reduce emissions of diesel particulate matter, oxides of nitrogen and other criteria pollutants, from in-use heavy-duty diesel-fueled vehicles. Title 13, Section 2025, 2008. 
12. California Code of Regulations, In-use on-road diesel-fueled heavy-duty drayage trucks. Title 13, Section 2027, 2008.

13. Code of Federal Regulations, $\mathrm{NO}_{\mathrm{x}}$ plus $\mathrm{NMHC}$ and particulate averaging, trading and banking for heavy-duty engines. Title 40, Section 86.004-15, 2000.

14. California Code of Regulations, Amendments to the Regulation to Reduce Emissions of Diesel Particulate Matter, Oxides of Nitrogen and Other Criteria Pollutants From In-Use OnRoad Diesel-Fueled Vehicles;. Title 13, Section 2025, 2011.

15. Code of Federal Regulations, Transient Test Cycle Generation. Title 40, Section 86.1333, 2014.

16. May, A. A.; Nguyen, N. T.; Presto, A. A.; Gordon, T. D.; Lipsky, E. M.; Karve, M.; Gutierrez, A. r.; Robertson, W. H.; Zhang, M.; Brandow, C.; Chang, O.; Chen, S.; CiceroFernandez, P.; Dinkins, L.; Fuentes, M.; Huang, S.-M.; Ling, R.; Long, J.; Maddox, C.; Massetti, J.; McCauley, E.; Miguel, A.; Na, K.; Ong, R.; Pang, Y.; Rieger, P.; Sax, T.; Truong, T.; Vo, T.; Chattopadhyay, S.; Maldonado, H.; Maricq, M. M.; Robinson, A. L., Gas- and particle-phase primary emissions from in-use, on-road gasoline and diesel vehicles. Atmos. Environ. 2014, 88, 247-260, DOI: 10.1016/j.atmosenv.2014.01.046.

17. Johnson, K. C.; Durbin, T. D.; Jung, H.; Cocker, D. R.; Bishnu, D.; Giannelli, R., Quantifying In-Use PM Measurements for Heavy Duty Diesel Vehicles. Environ. Sci. Technol. 2011, 45, (14), 6073-6079, DOI: 10.1021/es104151v.

18. Wu, Y.; Carder, D.; Shade, B.; Atkinson, R.; Clark, N.; Gautam, M. In A CFR1065Compliant Transportable/On-Road Low Emissions Measurement Laboratory with Dual Primary Full-Flow Dilution Tunnels, ASME 2009 Internal Combustion Engine Division Spring Technical Conference, Milwaukee, WI, 2009; pp 399-410, DOI: 10.1115/ICES2009-76090. 
19. Pierson, W. R.; Gertler, A. W.; Robinson, N. F.; Sagebiel, J. C.; Zielinska, B.; Bishop, G. A.; Stedman, D. H.; Zweidinger, R. B.; Ray, W. D., Real-world automotive emissions Summary of studies in the Fort McHenry and Tuscarora Mountain tunnels. Atmos. Environ. 1996, 30, (12), 2233-2256, DOI: 10.1016/1352-2310(95)00276-6.

20. Ban-Weiss, G. A.; McLaughlin, J. P.; Harley, R. A.; Lunden, M. M.; Kirchstetter, T. W.; Kean, A. J.; Strawa, A. W.; Stevenson, E. D.; Kendall, G. R., Long-term changes in emissions of nitrogen oxides and particulate matter from on-road gasoline and diesel vehicles. Atmos.

Environ. 2008, 42, 220-232, DOI: 10.1016/j.atmosenv.2007.09.049.

21. Fujita, E. M.; Campbell, D. E.; Zielinska, B.; Chow, J. C.; Lindhjem, C. E.; DenBleyker, A.; Bishop, G. A.; Schuchmann, B. G.; Stedman, D. H.; Lawson, D. R., Comparison of the MOVES2010a, MOBILE6.2 and EMFAC2007 mobile source emissions models with on-road traffic tunnel and remote sensing measurements. J. Air Waste Manage. Assoc. 2012, 62, (10), 1134-1149, DOI: 10.1080/10962247.2012.699016.

22. Kozawa, K. H.; Park, S. S.; Mara, S. L.; Herner, J. D., Verifying Emission Reductions from Heavy-Duty Diesel Trucks Operating on Southern California Freeways. Environ. Sci. Technol. 2014, 48, (3), 1475-1483, DOI: 10.1021/es4044177.

23. Bishop, G. A.; Morris, J. A.; Stedman, D. H.; Cohen, L. H.; Countess, R. J.; Countess, S. J.; Maly, P.; Scherer, S., The effects of altitude on heavy-duty diesel truck on-road emissions. Environ. Sci. Technol. 2001, 35, 1574-1578, DOI: 10.1021/es001533a.

24. Bishop, G. A.; Schuchmann, B. G.; Stedman, D. H.; Lawson, D. R., Emission Changes Resulting from the San Pedro Bay, California Ports Truck Retirement Program. Environ. Sci. Technol. 2012, 46, 551-558, DOI: 10.1021/es202392g. 
25. Bishop, G. A.; Schuchmann, B. G.; Stedman, D. H., Heavy-Duty Truck Emissions in the South Coast Air Basin of California. Environ. Sci. Technol. 2013, 47, (16), 9523-9529, DOI: 10.1021/es401487b.

26. Dallmann, T. R.; Harley, R. A.; Kirchstetter, T. W., Effects of Diesel Particle Filter Retrofits and Accelerated Fleet Turnover on Drayage Truck Emissions at the Port of Oakland. Environ. Sci. Technol. 2011, 45, 10773-10779, DOI: 10.1021/es202609q.

27. Dallmann, T. R.; DeMartini, S. J.; Kirchstetter, T. W.; Herndon, S. C.; Onasch, T. B.; Wood, E. C.; Harley, R. A., On-Road Measurement of Gas and Particle Phase Pollutant Emission Factors for Individual Heavy-Duty Diesel Trucks. Environ. Sci. Technol. 2012, 46, 8511-8518, DOI: 10.1021/es301936c.

28. Ban-Weiss, G. A.; Lunden, M. M.; Kirchstetter, T. W.; Harley, R. A., Measurement of black carbon and particle number emission factors from individual heavy-duty trucks. Environ. Sci. Technol. 2009, 43, 1419-1424, DOI: 10.1021/es8021039.

29. Texas A\&M Transportation Institute, Heavy-duty Diesel Inspection and Maintenance Pilot Program; College Station, TX, 2013; http://www.nctcog.org/trans/air/hevp/documents/NCTCOG_DieselIM_Final_Report_UpdatedOc tober2013.pdf.

30. Envirotest Canada, Remote Sensing Device Trail for Monitoring Heavy-duty Vehicle Emissions; Burnaby, BC Canada, 2013; http://www.metrovancouver.org/about/publications/Publications/2013 RSD HDV Study.pdf. 31. Mamakos, A.; Ntziachristos, L.; Samaras, Z., Evaluation of the Dekati Mass Monitor for the Measurement of Exhaust Particle Mass Emissions. Environ. Sci. Technol. 2006, 40, (15), 4739-4745, DOI: 10.1021/es052302c. 
32. Khalek, I. A., 2007 diesel particualte measurement research - phase 1; Alpharetta, GA, 2005; http://www.crcao.com/reports/recentstudies2005/Final\%20Rport-10415-Project\%20E-66Phase\%201--R3.pdf.

33. San Pedro Bay Ports Clean Air Action Plan: About the Clean Air Action Plan. Port of Long Beach; Port of Los Angeles. http://www.cleanairactionplan.org/about_caap/default.asp (June 2011).

34. Misra, C.; Collins, J. F.; Herner, J. D.; Sax, T.; Krishnamurthy, M.; Sobieralski, W.; Burntizki, M.; Chernich, D., In-Use NOx Emissions from Model Year 2010 and 2011 HeavyDuty Diesel Engines Equipped with Aftertreatment Devices. Environ. Sci. Technol. 2013, 47, (14), 7892-7898, DOI: $10.1021 / \mathrm{es} 4006288$.

35. Burgard, D. A.; Bishop, G. A.; Stedman, D. H.; Gessner, V. H.; Daeschlein, C., Remote sensing of in-use heavy-duty diesel trucks. Environ. Sci. Technol. 2006, 40, 6938-6942, DOI: 10.1021/es060989a.

36. Khalek, I. A.; Blanks, M. G.; Merritt, P. M., Phase 2 of the advanced collarorative emissions study; Alpharetta, GA, 2013;

http://crcao.org/reports/recentstudies2013/ACES\%20Ph2/03-17124_CRC\%20ACES\%20Phase2\%20FINAL\%20Report_Khalek-R6-SwRI.pdf. 


\section{Supporting Information For:}

\section{On-road Heavy-duty Vehicle Emissions Monitoring System}

Gary A. Bishop*, Rachel Hottor-Raguindin and Donald H. Stedman

Department of Chemistry and Biochemistry, University of Denver, Denver CO 80208

Peter McClintock

Applied Analysis, 13700 Marina Pointe Dr. Unit 301, Marina Del Rey, CA 90292

Ed Theobald

Envirotest Canada, 207-6741 Cariboo Rd., Burnaby British Columbia, Canada V3N4A3

Jeremy D. Johnson, Doh-Won Lee and Josias Zietsman

Texas A\&M Transportation Institute, 3135 TAMU, Texas A\&M University, College Station, TX 77843

Chandan Misra

California Air Resources Board, 1001 I St. Sacramento, CA 95814

*Corresponding author email: gbishop@du.edu; phone: (303) 871-2584

\section{Summary of Supporting Information:}

9 Pages (excluding cover):

Tables S1, S2

Figures S1 - S7 
Table S1. Summary of instruments with corresponding operating principle, species measured, range, repeatability and response time.

\begin{tabular}{|c|c|c|c|c|}
\hline Model & Operating Principle & Species & $\begin{array}{c}\text { Range } \\
\text { (Repeatability) }\end{array}$ & $\begin{array}{l}\text { Response } \\
\text { Time }\end{array}$ \\
\hline Horiba AIA-240 & $\begin{array}{l}\text { Non-dispersive infrared } \\
\text { absorptiometry }\end{array}$ & $\mathrm{CO} / \mathrm{CO}_{2}$ & $\begin{array}{c}\mathrm{CO}-0 \text { to } 1.0 \text { vol\% } \\
\text { ( } \pm 1 \% \text { max value) } \\
\mathrm{CO}_{2}-0 \text { to } 4.0 \text { vol\% } \\
( \pm 1 \% \text { max value })\end{array}$ & $1.5 \mathrm{~s}$ \\
\hline Horiba FCA-240 & $\begin{array}{l}\text { Hydrogen flame } \\
\text { ionization detector }\end{array}$ & THC & $\begin{array}{l}0-2000 \text { ppm-C } \\
( \pm 1 \% \text { full scale })\end{array}$ & $1.5 \mathrm{~s}$ \\
\hline Horiba FCA-240 & $\begin{array}{c}\text { Ozone } \\
\text { Chemiluminescence }\end{array}$ & $\mathrm{NO} / \mathrm{NO}_{\mathrm{x}}$ & 0 to $500 \mathrm{ppm}$ & $\begin{array}{l}\mathrm{NO} 1.0 \mathrm{~s} \\
\mathrm{NO}_{\mathrm{x}} 3.0 \mathrm{~s}\end{array}$ \\
\hline $\begin{array}{c}\text { Dekati } \\
\text { DMM-230A }\end{array}$ & $\begin{array}{l}\text { Density measurement } \\
\text { principle }\end{array}$ & Particulate & 0 to $1.2 \mu \mathrm{m}$ & $<5 s$ \\
\hline $\begin{array}{c}\text { Droplet Measurement } \\
\text { Technologies PAX }\end{array}$ & $\begin{array}{c}\text { Photoacoustic } \\
\text { Extinctiometer }(870 \mathrm{~nm})\end{array}$ & $\begin{array}{l}\text { Black } \\
\text { Carbon }\end{array}$ & $\begin{array}{l}<1 \mathrm{Mm}^{-1} \text { to } \\
100,000 \mathrm{Mm}^{-1}\end{array}$ & $<10 \mathrm{~s}$ \\
\hline
\end{tabular}

${ }^{\text {a }} \mathrm{NO}_{\mathrm{x}}$ measurements are collected using a second Horiba FCA-240 with a catalyst that converts any $\mathrm{NO}_{2}$ to $\mathrm{NO}$.

${ }^{\mathrm{b}}$ Mass absorption cross section of $4.74 \mu^{-3}$ used to convert absorption to BC concentration. 
Table S2. Field determined scaling factors for the OHMS gaseous analyzers.

\begin{tabular}{|c|c|c|c|c|}
\hline Location & $\mathrm{CO} / \mathrm{CO}_{2}$ & $\mathrm{HC} / \mathrm{CO}_{2}$ & $\mathrm{NO} / \mathrm{CO}_{2}$ & $\mathrm{NO}_{\mathrm{x}} / \mathrm{CO}_{2}$ \\
\hline Port of LA & 0.9 & 3.68 & 0.98 & 1.02 \\
\hline Cottonwood & 0.8 & 2.94 & 1.04 & 1.02 \\
\hline
\end{tabular}

Certified BAR-97 Low range cylinder with 0.5\% CO, 6\% $\mathrm{CO}_{2}, 200 \mathrm{ppm}$ propane, $300 \mathrm{ppm}$ NO in nitrogen used to determine scaling factors. 


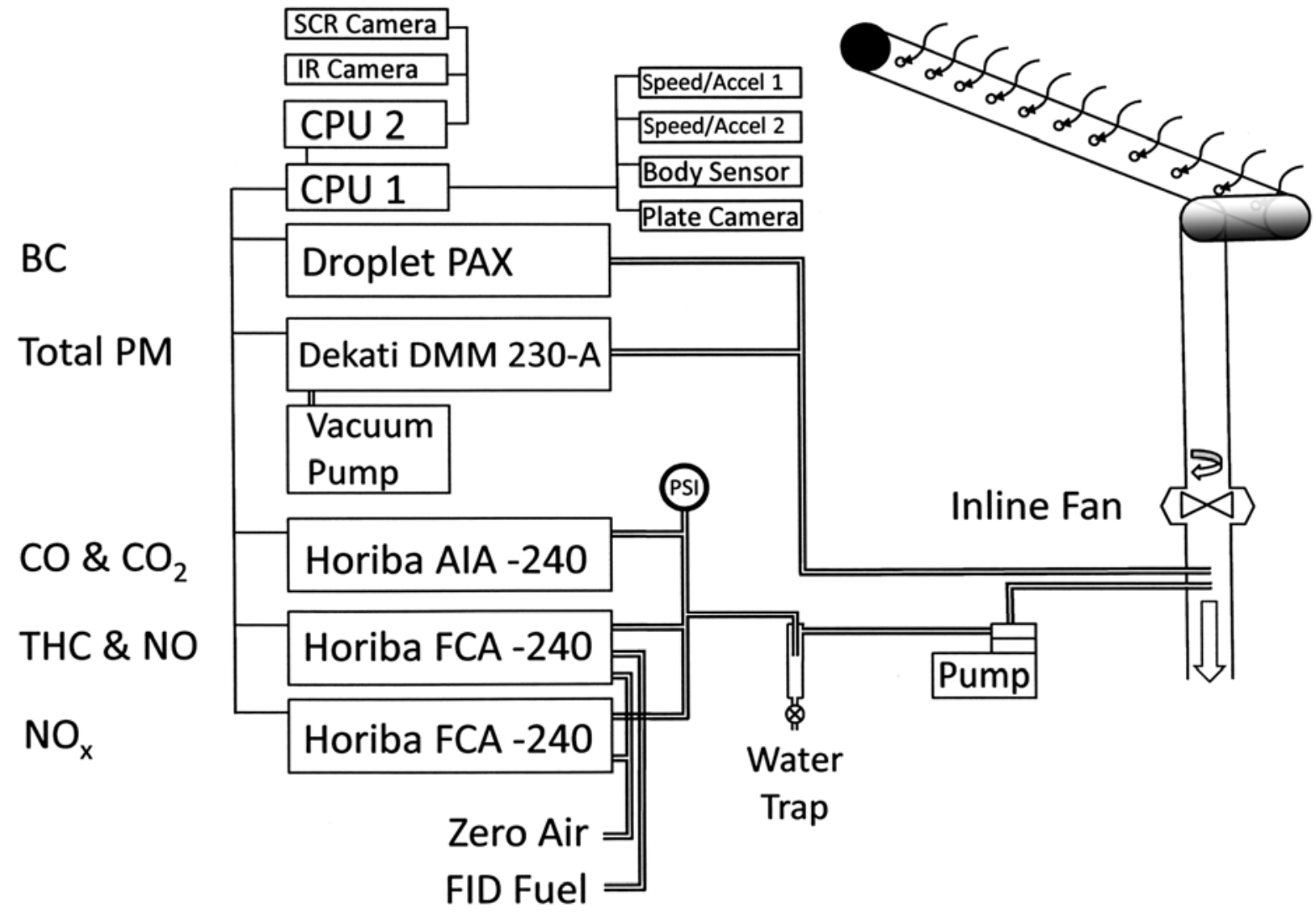

Figure S1. Schematic drawing (not to scale) of the OHMS emission sampling setup. 


\section{Example Truck Plumes:}

When a vehicle exits the tent an infrared body sensor triggers all of the cameras and the main data collection cpu1 collects $1 \mathrm{~Hz}$ voltage data from the five analyzers. The voltages are converted to the appropriate units for each analyzer using each instrument's response equations. Figures S2 and S3 show the converted second by second data collected from a 2003 Freightliner at the Cottonwood weigh station. These data have not been time aligned and the total $\mathrm{NO}_{\mathrm{x}}$ analyzer and the two particulate instruments have noticeable time lags. Provided that the $\mathrm{CO}_{2}$ concentrations increase by more than $75 \mathrm{ppm}$ (our minimum plume size criteria) above the background levels the data are time aligned and correlated against $\mathrm{CO}_{2}$ and a least squares line is fit to the data and the slope of that line is the unadjusted fuel specific emissions ratio. Figures S4 and S5 show the correlation plots for the time aligned data for the five species measured and each data set's best fit line. Note that in Figure $\mathrm{S} 4$ the $\mathrm{NO}_{\mathrm{x}} / \mathrm{CO}_{2}$ correlation data have been vertically offset to better show the data points. For this vehicle the data points in the particulate correlations have noticeably more scatter than the gaseous data which can result from higher particle emissions during gear shifts at ratios to $\mathrm{CO}_{2}$ which are different than the dominant driving mode.

Each linear least squares fit is quality checked against a set of error criteria and ratios meeting those criteria are marked as valid in the data record. Valid ratios are adjusted by dividing by each species scaling factors (see Table S2) determined using the gas calibration mixtures described in the text. These adjusted ratios reported are mole ratios which are moles of the particular species ratioed to the moles of carbon emitted as detailed in equation (1).

$$
\frac{\text { moles pollutant }}{\text { moles } C}=\frac{\text { pollutant }}{\mathrm{CO}+\mathrm{CO}_{2}+3 \mathrm{HC}}=\frac{\left(\frac{\text { pollutant }}{\mathrm{CO}_{2}}\right)}{\left(\frac{\mathrm{CO}}{\mathrm{CO}_{2}}\right)+1+3\left(\frac{\mathrm{HC}}{\mathrm{CO}_{2}}\right)}
$$

Moles of pollutant are converted to grams by multiplying by the molecular weight of the species and the moles of carbon in the exhaust are converted to kilograms by multiplying the result by $0.014 \mathrm{~kg}$ of fuel per mole of carbon in the fuel (this assumes a carbon mass fraction of 0.86 ), assuming the fuel is stoichiometrically $\mathrm{CH}_{2}$. ${ }^{1}$ 


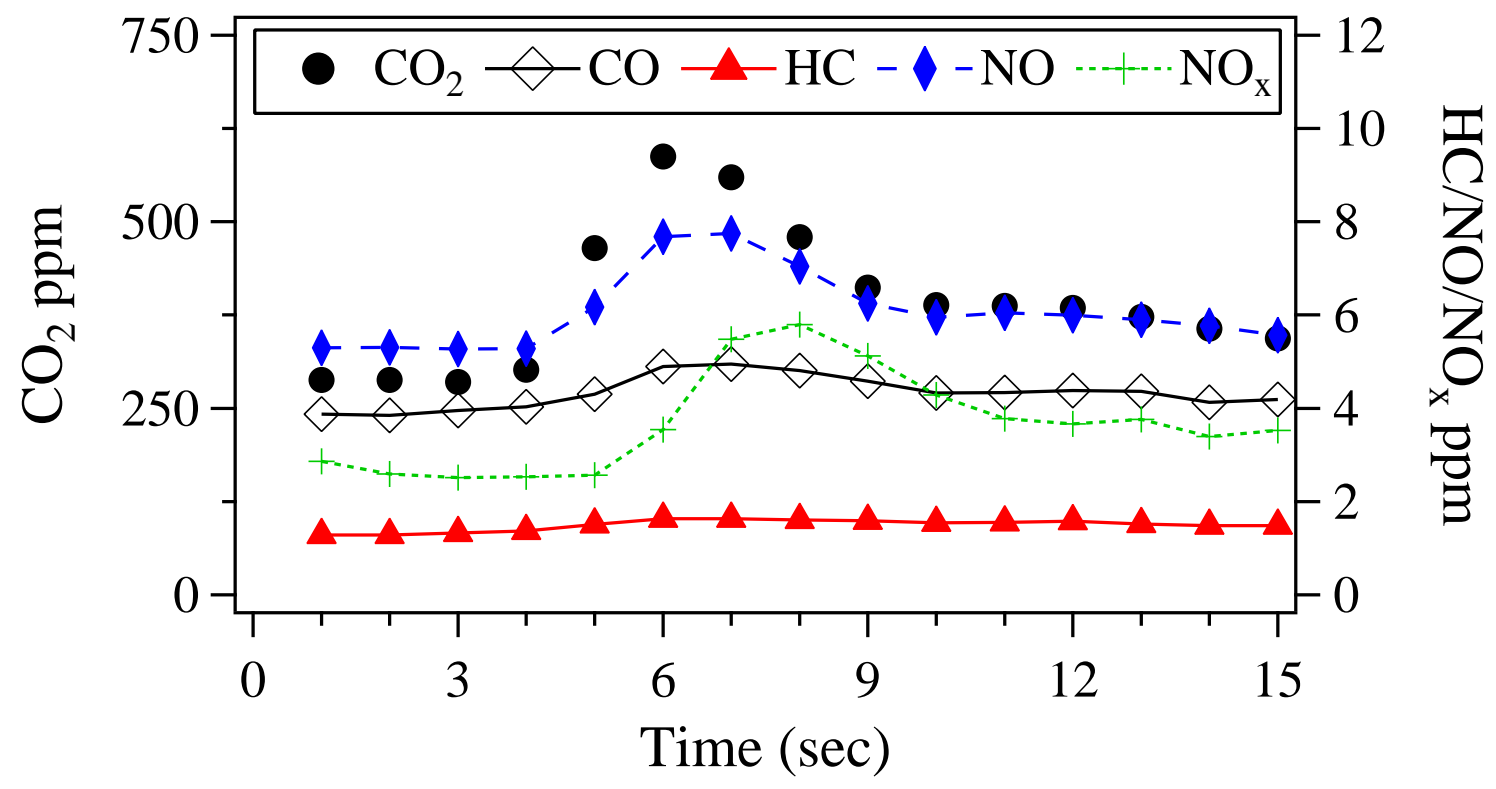

Figure S2. Concentration time series for the gaseous species from a 2003 Freightliner measured at the Cottonwood weigh station. $\mathrm{CO}_{2}$ data (black circles) are plotted on the left axis while the CO (black open diamonds), HC (red triangles), NO (blue filled diamonds) and $\mathrm{NO}_{\mathrm{x}}$ (green pluses) are plotted on the right axis. Data are not time aligned.

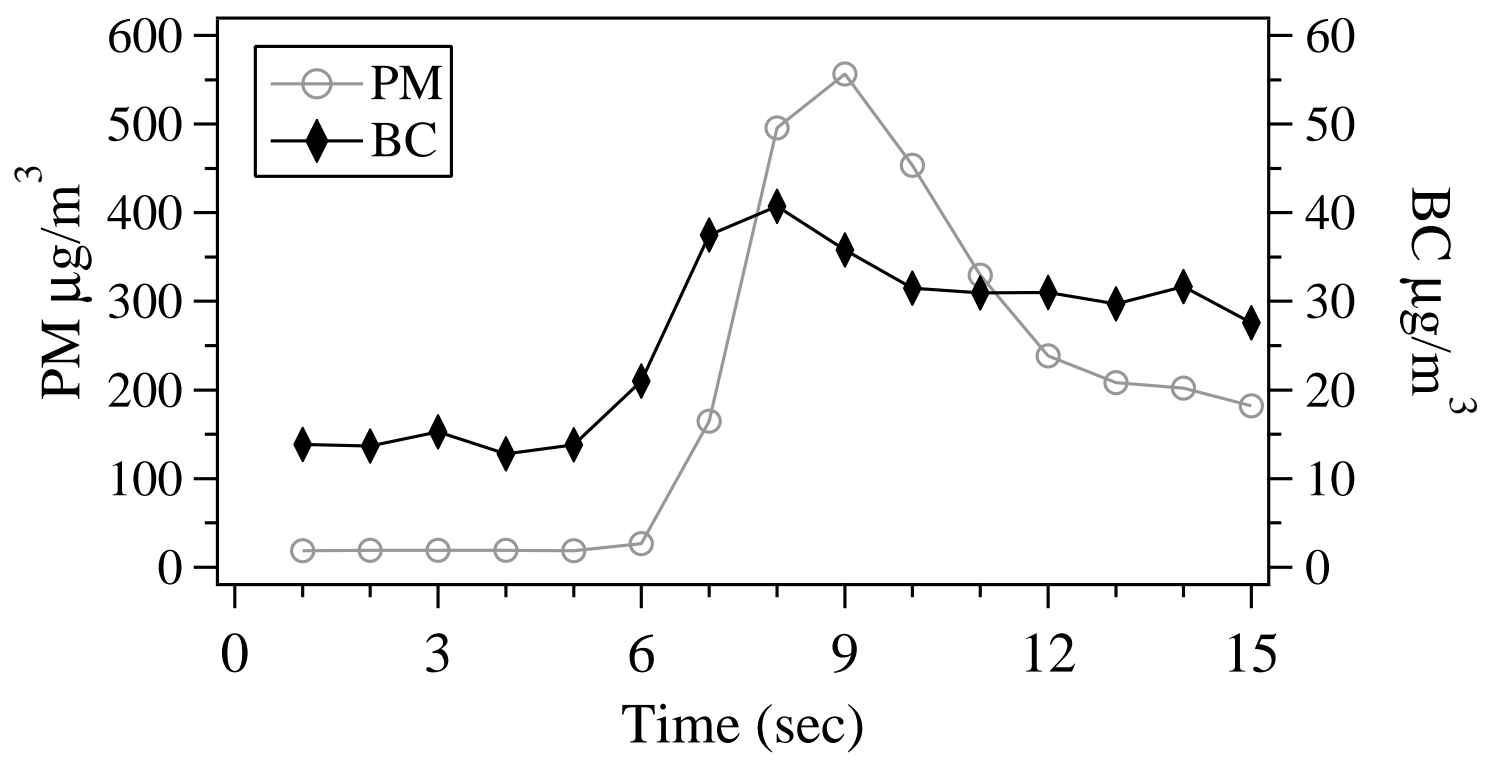

Figure S3. Concentration time series for the particulate emissions from a 2003 Freightliner measured at the Cottonwood weigh station. Total PM mass (grey circles) data are plotted on the left axis and the BC mass (black diamonds) are plotted on the right axis. Data are not time aligned. 


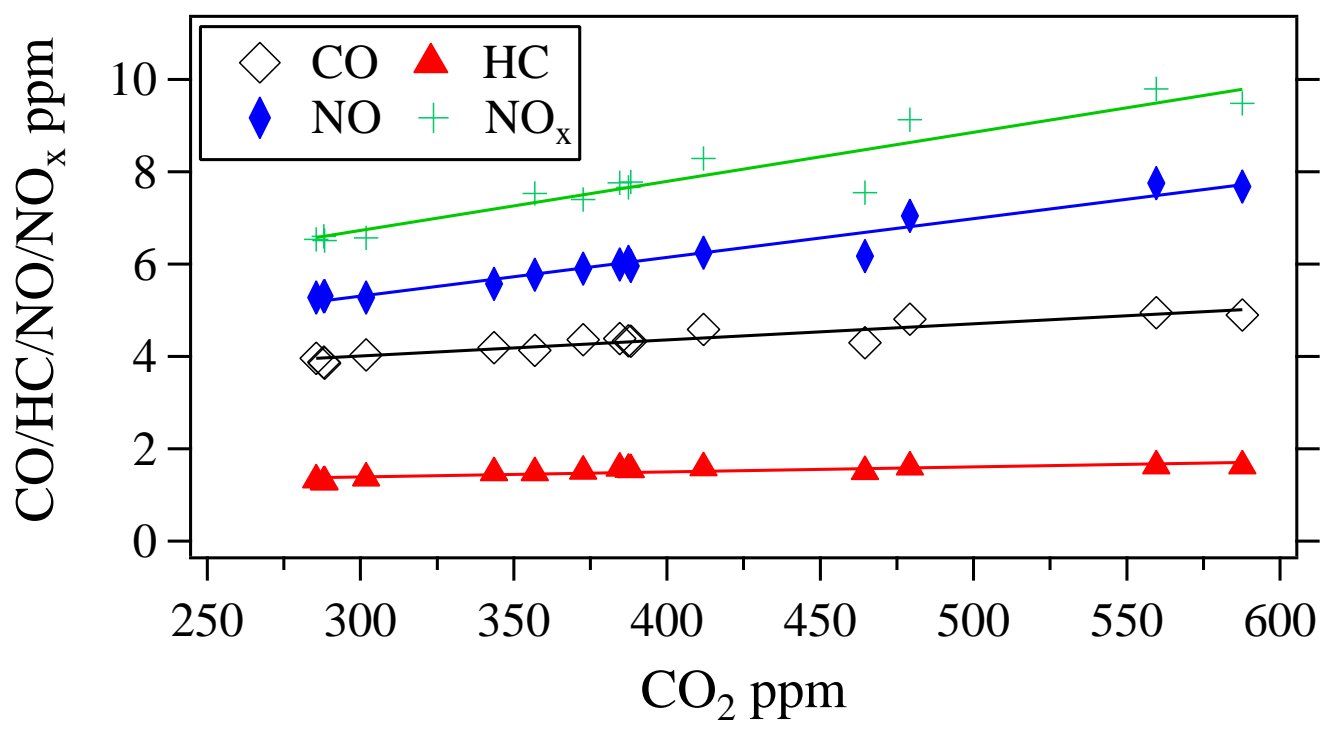

Figure S4. Correlation plots for each of the gaseous species time aligned data against $\mathrm{CO}_{2}$ for the 2003 Freightliner measured at the Cottonwood weigh station. The $\mathrm{NO}_{\mathrm{x}}$ concentration data have been offset from their true values to clearly show the data points and due to time offsets it only contains 14 data points.

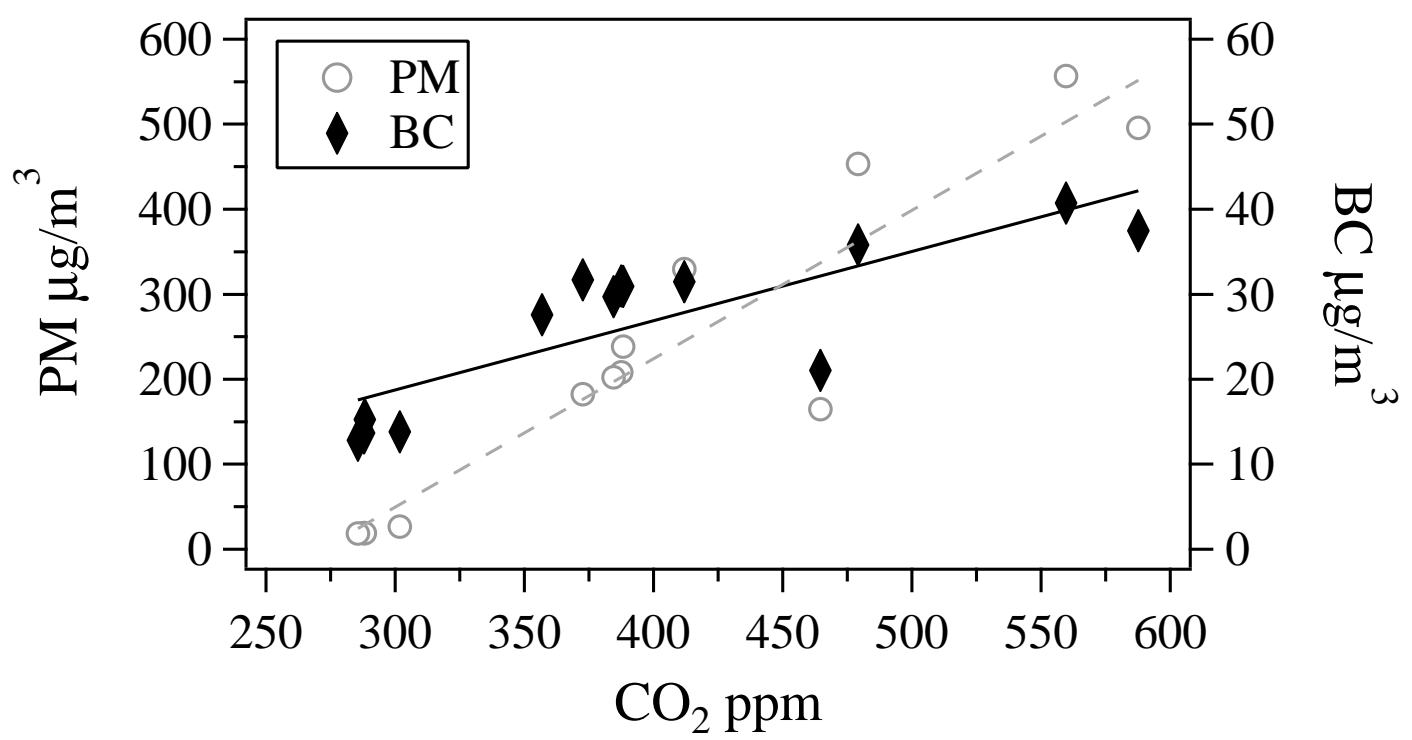

Figure S5. Correlation plots for each of the particle species time aligned data against $\mathrm{CO}_{2}$ for the 2003 Freightliner measured at the Cottonwood weigh station. Due to time offsets the PM correlation only contains 13 data points and the BC correlation only contains 14 data points. Also note that these correlations data exhibit more scatter than the gaseous data likely a result of gear shifting that can change the emission ratio very quickly. 


\section{$\mathrm{NO}_{\mathrm{x}}$ Intercomparison and Catalyst Conversion Efficiency Checks}

During the Texas tests in the summer of 2012 an intercomparison was made of $\mathrm{NO}_{\mathrm{x}}$ emissions using ten portable emissions measurement system (PEMS) equipped trucks accelerating from a stop through the OHMS setup. ${ }^{2}$ The correlation between the two sets of measurements was quite good with an $\mathrm{R}^{2}$ of 0.81 but the $\mathrm{OHMS} \mathrm{gNO}_{\mathrm{x}} / \mathrm{kg}$ readings were on average $80 \%$ higher (slope $=$ 1.8, see Figure S6). Attempted field calibrations in Texas of the total $\mathrm{NO}_{\mathrm{x}}$ analyzers $\mathrm{NO}_{2}$ catalyst conversion efficiency, by injecting a certified $\mathrm{NO}_{2} / \mathrm{CO}_{2}\left(91.1 \mathrm{ppm} \mathrm{NO}\right.$ in $2.99 \% \mathrm{CO}_{2}$, Air Liquide) ratio into the sampling system with a plastic syringe, resulted in a conversion efficiency of only $10 \%$. Additional calibrations in Vancouver and California also resulted in analyzer $\mathrm{NO}_{2}$ catalyst conversion efficiencies that were lower than expected with a range of 44 to $73 \%$. Convinced that we were over reporting $\mathrm{NO}_{2}$ and thus total $\mathrm{NO}_{\mathrm{x}}$ emissions we challenged our two $\mathrm{NO} / \mathrm{NO}_{\mathrm{x}}$ analyzers in the lab with an ozone titration of $\mathrm{NO}$ experiment. Figure $\mathrm{S} 7$ plots the results of that titration which indicated, that within experimental error, the total $\mathrm{NO}_{\mathrm{x}}$ instruments catalyst had a 100\% conversion efficiency for $\mathrm{NO}_{2}$. This combined with the results of the Texas PEMS intercomparison confirmed that our field calibrations had been inaccurate resulting in the over reporting of $\mathrm{NO}_{2}$ and total $\mathrm{NO}_{x}$. Either the syringe material (polycarbonate) is reacting with the higher concentrations of $\mathrm{NO}_{2}$ used for the field calibrations, or $\mathrm{NO}_{2}$ is being lost to the walls of the piping and or tubing. For the most recent measurements in California we relied upon the laboratory calibration indicating $100 \%$ conversion efficiency for $\mathrm{NO}_{2}$ and scaled the data accordingly. 


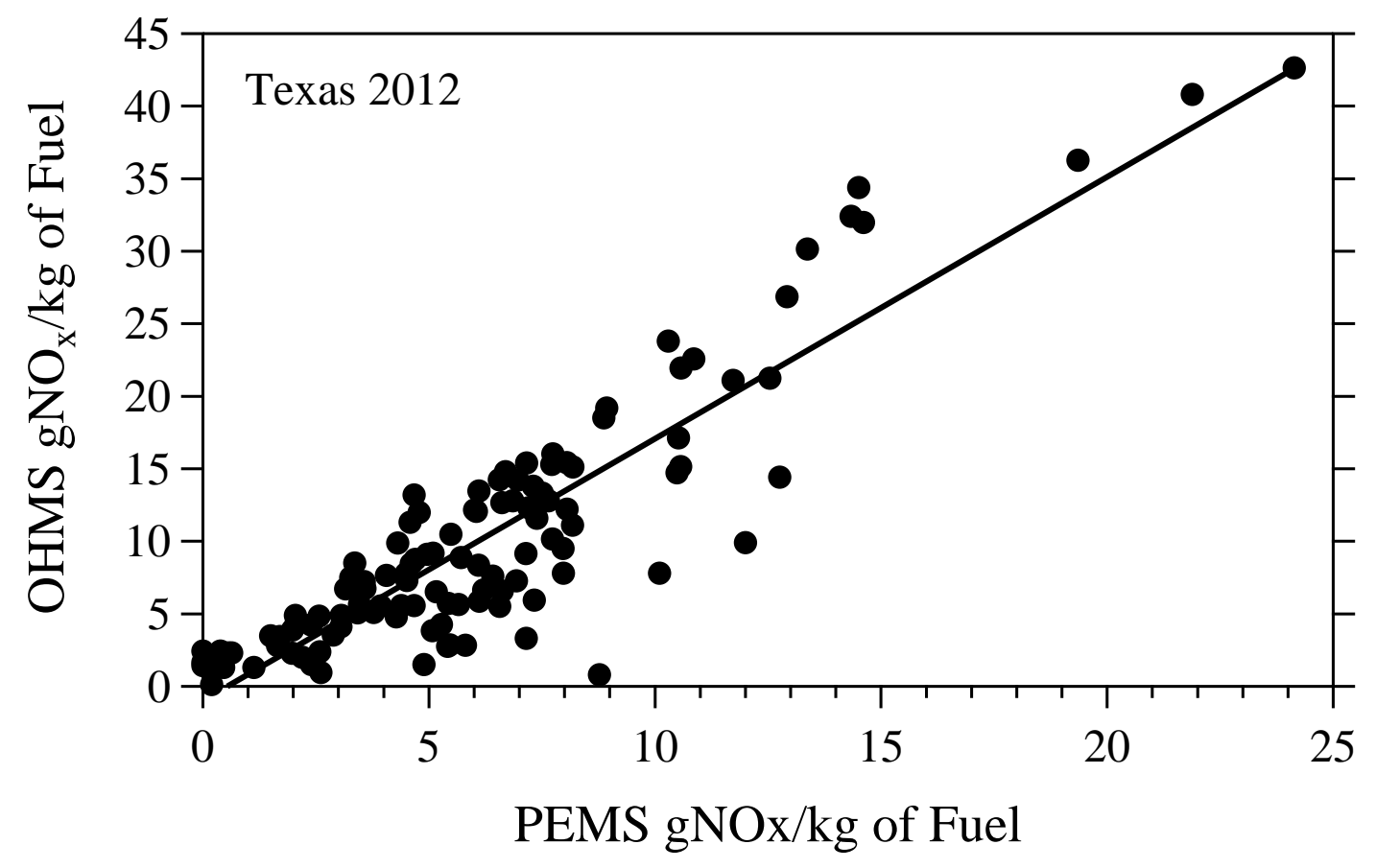

Figure S6. OHMS and portable emissions measurement system (PEMS) $\mathrm{gNO}_{\mathrm{x}} / \mathrm{kg}$ of fuel intercomparison conducted at the New Waverly weigh station on NB I-45 in Texas. PEMS unit utilized was a SEMTECH-DS from Sensors, Inc. The least squares best fit line has a slope of 1.8 and an $\mathrm{R}^{2}$ of 0.81 .

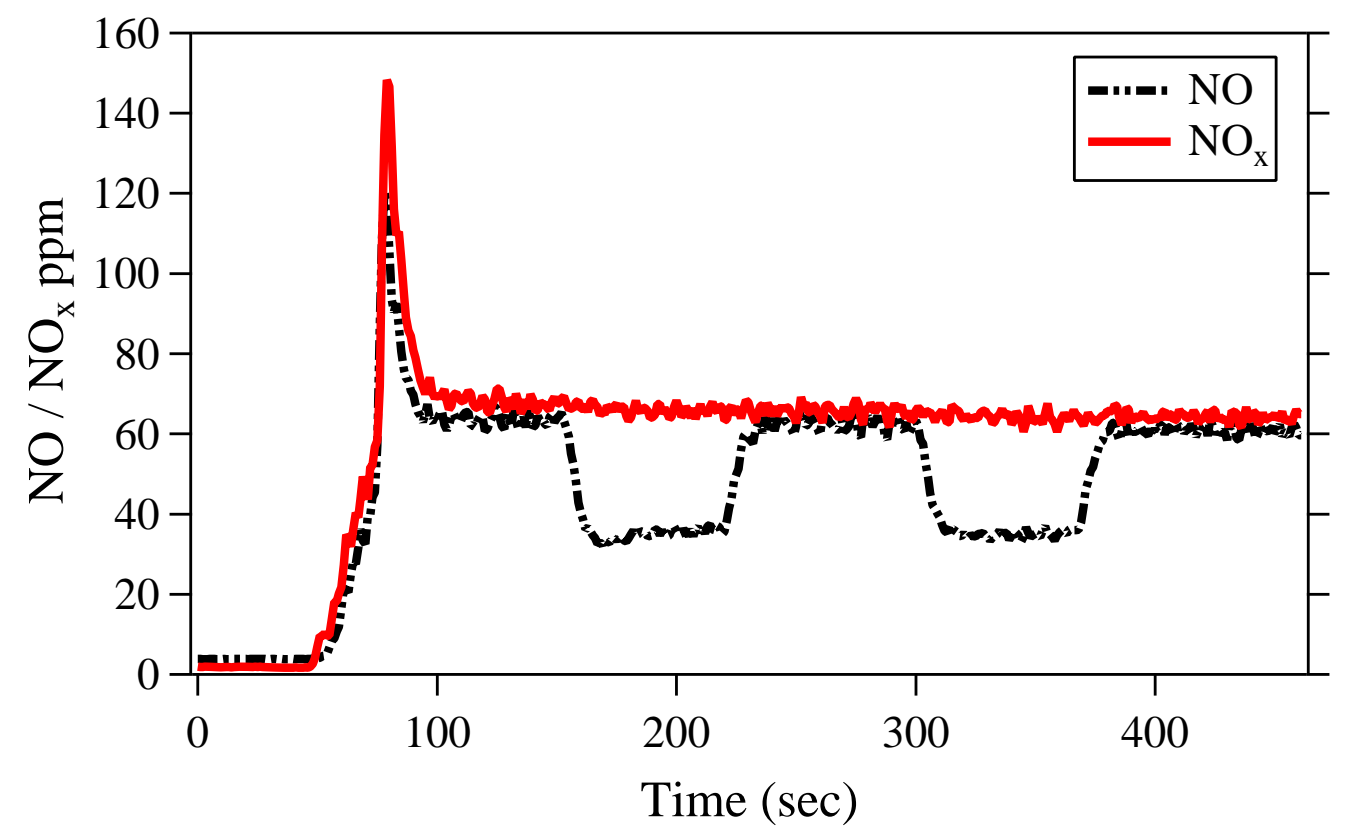

Figure S7. NO (black dashed line) and $\mathrm{NO}_{\mathrm{x}}$ (red line) concentrations versus time during an ozone titration of NO. The large peak at the beginning is from opening the NO cylinder and after equilibration the ozone generator is turned on at a level which titrates about half of the $\mathrm{NO}$ in the sampling stream leaving the total $\mathrm{NO}_{\mathrm{x}}$ concentration unaffected. 
1. FEAT Math II. Bishop, G. A.

http://www.feat.biochem.du.edu/assets/reports/FEAT_Math_II.pdf .

2. Texas A\&M Transportation Institute, Heavy-duty Diesel Inspection and Maintenance Pilot Program; College Station, TX, 2013;

http://www.nctcog.org/trans/air/hevp/documents/NCTCOG_DieselIM_Final_Report_UpdatedOc tober2013.pdf. 